\title{
Advancing Understanding about the Relationship between Science, University and Society - An Introduction
}

\author{
Juha Tuunainen \\ University of Oulu, Finland/juha.tuunainen@oulu.fi \\ Kari Kantasalmi \\ University of Helsinki, Finland/ kari.kantasalmi@helsinki.fi
}

The relationship between science, university and society has been a topic of research in the broad areas of science, technology and innovation studies as well as higher education research for a long time; at least since the seminal dissertation of Robert K. Merton was published in Osiris in 1938 (Merton, 1938). In this groundbreaking work, Merton set out to understand, first, the social and cultural dynamics of science in the late $17^{\text {th }}$ century England and, second, to understand the shifts in patterns of interest in various fields of science and technology. Although Merton's discussion about the dynamics of scientific activity during this period of time was cautious and he tried to dissociate himself from "any enterprise that sought to account for the scientific method or knowledge by reference to social or economic considerations", his work can be regarded as an intellectual kindling for later debates about "internal" and "external" factors affecting the development of science in society (Shapin, 1988: 594).

From today's perspective, Merton's study and the research on the dynamics of science and university in society that has evolved ever since, also marks the starting point of this special issue, an endeavour which has evolved during a series of sessions organised by Research Committees 04 (Sociology of Education) and 23 (Sociology of Science and Technology) of the International Sociological Association (ISA).

As is evident, the broad topic of this special issue is both theoretically extensive and empirically heterogeneous. The evolution of the field not only covers a long time frame, starting at the inception of science studies and ending at present times, but also includes a whole variety of theories developed at different levels of abstraction. These are: 1) research theories that are related to specific domains of empirical research, 2) diagnoses of our times, or 'performative histories' (Godin, 1998), that are messages sent out from scholarly conversation to a wider learned public and 3) general theory of sociology that addresses social theory, the constitution of the social and theory of society (e.g. Joas and Knöbl, 2009; Hammershøj, 2015).

A majority of the literature in science, university and society relations obviously represent research theories, i.e. theories that empirically analyse some specific phenomenon in a concrete social context. These types of theories have been developed, for instance in relation to the ways in which citizen groups understand and become engaged in 
science (see Irwin, 2015), the use of scientific results, concepts or technologies in society (e.g. Parthasarathy, 2012), or the ways in which scientists manage boundaries between science and other knowledge forms (e.g. Leith et al., 2016). There is also much literature in science-society interaction which belongs to the diagnoses of the era type of thinking. These theories typically seek to answer questions about what the nature of our epoch is, they are often normative in nature and they endeavour to yield new topical insight. Examples of such theories include the evolving literature about the triple helix of universityindustry-government relations (Etzkowitz, 2008) and Mode 2 of knowledge production (Nowotny et al., 2001).

Instead of providing an exhaustive account of intellectual development and heterogeneous debates associated with all of such literature, we will set the stage for the current special issue by way of discussing the relationship between science, university and society with the help of those theories that have been taken up by the articles included in this volume. Once we have briefly considered these theories in their original form, and after we have summarised the articles included in this special issue, we will search for the possibilities for increasing connectivity between different studies at the level of general sociological theory. For this purpose, we will draw ideas from an approach which we regard as a fruitful source of insight to understand the topic in question, namely Luhmann's systems theory (Luhmann, 1995), his theory of society (Luhmann, 2012,2013 ) and his application of these general theories in the sociological analysis of the societal system of science (Luhmann, 1990).

Let us begin, however, with some of the most widely used theories of science-society interaction as referred to by the authors of this volume. Although these theories, namely the triple helix of university-industry-government relations (Etzkowitz, 2008), Mode 2 knowledge production (Nowotny et al., 2001) and academic capitalism (Rhoades and Slaughter, 2004), have been around for two decades now, they still figure as major models of science's transformation and are regularly used in the current research as reference points to the topic (see, e.g. Bychova, 2016;
Fochler, 2016; Boggio et al., 2016; Hoffman, 2015; McLevey, 2015; Hicks and Wang, 2013; Parker and Crona, 2012; Randalls, 2010; Lam, 2010).

\section{Theories about science, university and society}

In parallel with the growing emphasis put on the post-war science, technology and innovation policies, research in science studies has asserted that a significant alteration has taken place in science and university organisation. Roughly speaking, two major positions can be discerned.

First, some authors state that a radical transformation of science and the university organisation has taken place. By using the metaphor of "the triple helix of university-industry-government relations" Etzkowitz (2008; also Gibbons, 2000) has claimed that the closer interaction between universities, industries and governments has given rise to a new kind of research which no longer primarily seeks to advance scientific knowledge but rather focuses on the development of commercially viable products. The triple helix is thus a metaphor that seeks to represent intensifying interaction and, indeed, a complex overlap between the institutional spheres of the university, industry and government. As a result, the boundaries between these spheres have become blurred so that "the extension of knowledge" becomes integrated into a compatible relationship with the "capitalization of knowledge" (Etzkowitz, 1998: 824-829). The increasing co-operation between the three spheres with particular interests in knowledge production also implies the emergence of the entrepreneurial university, a hybrid organisation which incorporates economic development alongside scientific research and higher education, for instance, through technology transfer offices, spin-off firms and science parks (Etzkowitz, 2008).

Another example of such a radical theoretical stance is the Mode 2 knowledge production thesis (Nowotny et al., 2001; Gibbons et al., 1994), which claims that science increasingly has become fused with other societal forms of practice. It states that research problems are no longer set and solved within the academic community but, instead, in relation to co-operations with their societal 
contexts. Compared with the previous Mode 1 science, which subscribes to knowledge produced within autonomous disciplinary communities, Mode 2 science operates within more permeable organisational boundaries, and is managed for the achievement of particular useful purposes, such as a technological application or commercial innovation (Gibbons et al., 1994: 3-6). Various locales and practitioners are thus involved in Mode 2 knowledge production, spanning from scientists of different disciplines to industrial researchers and other societal stakeholders (Gibbons et al., 1994: 32-33). According to the Mode 2 thesis, the emergence of a societally more integrative mode of knowledge production also parallels the transformation of the university: the organisational structure of the university has thus become "stretched" so as to respond to the needs of the economy as well as other societal institutions, such as that of mass education (Gibbons et al., 1994: 70-89; Nowotny et al., 2001: 79-94).

Whereas the above-mentioned models speak about a very profound transformation of science and the university, there are also moderate views on the change. According to these perspectives, the political use of market and marketlike mechanisms has increased in the fields of science, university and higher education. In their study of public universities operating in English-speaking countries, Slaughter, Leslie and Rhoades (Slaughter and Leslie, 1997; Rhoades and Slaughter, 2004), for instance, found that during the past two decades universities have become increasingly oriented towards "the profit motive" and "market-like" behaviour due to the neoliberal policies aimed at securing nations' competitiveness in the global economy. The resulting 'academic capitalism' refers to efforts by universities and individual scientists to secure research grants and other forms of external funding on the basis of which they can work in a situation where the basic funding of universities has diminished (Slaughter and Leslie, 1997: 8-9; Rhoades and Slaughter, 2004). This development has created a lot of tension, including the encouragement of professors to become commercially active simultaneously with their teaching duties being increased (Slaughter and Leslie, 1997: 8-9; Rhoades and Slaughter, 2004; cf. Münch 2015).
Despite these difficulties that have been extensively addressed (e.g. Münch, 2015; Wadmann 2014; Brown, 2010; Tuunainen and Knuuttila 2009; Tuunainen, 2005; Krimsky, 2003), Slaughter and Leslie maintain that academic, commercial and bureaucratic cultures are integrating and that the distance between universities, industries and governments is decreasing. Instead of being organisations oriented towards producing scientific knowledge under strong institutional autonomy, universities in this perspective are becoming engaged in what other scholars have called entrepreneurial, commercialised, privatised and post-academic science (e.g. Etzkowitz, 1998; Thackray, 1998; Radder, 2010; Mirowski, 2011; Ziman, 2000).

\section{Contributions in this volume}

While the above-mentioned theories discuss the transformation of science and the university in rather general diagnostic terms, our task in this special issue is to open up the subject to qualitative empirical research and explore, on that basis, the possible theoretical directions with the help of which an advanced understanding of the relations between science, university and society could be achieved. The first article by Norma Möllers draws from an ethnographical study of a governmentfunded, transdisciplinary research group which was engaged in the development of a "smart" video surveillance system for screening "dangerous" behaviour in public places. Anchoring her study in the discussion about the neoliberal technoscience (Lave et al., 2010), theories of transformation in science and the university (e.g. Gibbons et al., 1994; Etzkowitz, 2008) and symbolic interactionist perspective on scientific practice (e.g. Clarke and Star 2008), she directs attention to the ways in which scientists manage the conflicting demands present in "hybrid spaces" composed of academic and industrial actors and their divergent interests. More specifically, she uses the concepts of "forward tailoring" and "reverse tailoring" to understand how scientists translate either practical problems of research funders into research problems that are sensible in "scientific worlds" or, vice versa, scientific problems into ones that are close enough to those issues that 
funders want to have solved. Thus, the contested or negotiated conditioning of the forms of scientific problems becomes the centre of her empirical concern. The rich analysis of this kind of 'boundary work' (Gieryn, 1999) presented by the article increases our understanding of the various kinds of articulations and translations scientific practice rests upon at the grass-root levels of universities, simultaneously as it further elaborates the ways in which stability at the interface between science, government and the wider public can be achieved.

The second article by Pia Vuolanto also addresses the topic of boundary work between science and society, now in the context of a newly institutionalised field of nursing science. Making use of symbolic interactionist 'arena analysis' (Clarke and Star, 2008), she investigates the process whereby the representatives of different social worlds, such as those of medical specialists, sceptics, nurses and patients, pulled nursing science in different directions at an early stage of its academisation (Neave, 1979). Instead of being a clear example of neither Mode 1 or Mode 2 science nor an instance of transformation between these, nursing science in Vuolanto's account is a discipline which straddles two ideal-typical activities, which are the production of knowledge for the academic community and production of knowledge for societal stakeholders (cf. Albert and McGuire, 2014). Another way to understand and discuss the tension-laden relationship between nursing science and society, according to her, would be to see it serve distinct academic, corporate, professional, policy and public markets (Ylijoki et al., 2011), all of which require different kinds of contributions on the part of practising scientists. In addition to being interesting in shedding empirical light on the complex relationships between professionally oriented disciplines and different extra-scientific interests, Vuolanto's study also underlines the need to further theorize the ways in which different interests are being combined with or translated to one another for the purpose of providing a stable context for a new discipline to institutionalise. The article thus advances a small but evidently growing literature which combines research on boundary work with that of discipline formation (Kurath, 2015; Beddoes, 2014).

The third article by Manuela Fernández Pinto describes strategies used in the social construction of ignorance, especially when pursuing clearly commercially driven research. Her concern arises from the mutual changes in corporate research and university organisation. The former has turned the strategic view from the "in-house research labs" to the outsourcing of research and development (R\&D), while universities have increasingly adopted new forms of liaison with external funding sources. The Cold War era's R\&D regimes supported strategic deals within the military-industrial-academic complex (MIAC) in the political environment of universities that motivated the creation of costly research units inside MIAC relevant industrial corporations. Such arrangements have been partly restructured by the current research, development and innovation (R\&D\&l) regime, which stresses commercial research through wider societal engagements so as to produce innovations for differentiated markets, and thus find new potential for economic growth (see Kantasalmi, 2015). Such a switch of emphasis in the science policy regime and the related permeability of the university organisation present new issues for the organisation of scientific research. This happens, for instance, when organised secrecy of the Cold War classified knowledge becomes amended in grey zones of commercialised science in terms of 'limited secrecy' (Etzkowitz, 2011). To better understand the complicated changes in the organisational couplings of science and the university, we would need advanced conceptual guidance to regulate the consistency between the diagnoses of the times that speak about transformations in knowledge production and the university organisation, and the variety of empirically-based research theories that enrich them.

\section{In search of a more general theoretical view on science- university-society interaction}

As illustrated by the articles published in this special issue, transformations in the inner organisation of the $21^{\text {st }}$ century university system are 
becoming all the more obvious. Both STS and higher education research point to the processes that bring some sorts of "hybrids" to substitute for preceding pure forms, that is, differentiated formats of communication or logics of practices. These hybrids have a twofold meaning that relates to the sociological studies of scientific practices and the literature that speaks about the transformation of the university organisation.

First, hybrids address the fact that research groups are often simultaneously engaged in the production of societally useful end-products and the creation of related scientific knowledge. In this view, science is seen as a deeply societal endeavour where practical utility operates as the paramount justification for scientific research. As empirical research shows, combining theoretical understanding and societal use is not an extraordinary feature of scientific practice but, rather, a quite common attribute of much of the current science (e.g. Hessels, 2010; Miettinen et al. 2015; Powell et al., 2005; Tuunainen, 2001).

Second, the term hybrid refers to a corpus of research according to which the entire university organisation has been in a state of fundamental transformation. These studies, proliferating in the fields of higher education research and research policy, argue that financial considerations related to global economic competition have permeated academia. Science and technology policies have begun to emphasise potentially lucrative areas of research, while simultaneously universities have encountered hard times due to considerable cuts in governmental allowances. In consequence, universities' dependence on external funding has increased in tandem with the privatisation of research results. In the wake of these developments, universities are in a state of profound change (e.g. Etzkowitz, 2008; Owen-Smith, 2003, 2006; Marginson and Considine, 2000).

In order to advance our understanding of the nature of this conflation and the related forms of social order coming up at the interface of science, university and society, we want to point to the need for varying perspectives in the theoretical regulation of empirical observation at the level of general sociological theory, that is, theory of society and social theory concerned with the most general presumptions of the social sciences. In this regard, the recent developments in systems theory (Luhmann, 1995) and its application to societal theory (Luhmann, 2012; 2013) offer potentially useful concepts and ideas. The increasing precision in the empirical analysis of the changing forms of knowledge production in universities and the multiplicity of the diagnosisof-the-times type of theorising both underline the need for amplifying conceptual coherence at the level of sociological theory. Because all of the articles included in this special issue point to some sort of hybridity and the related demarcation problems between university and society, we believe that attention directed in different ways in which societal systems (e.g. science, education and economy) are coupled via organisations (e.g. universities) might prove to be a fruitful avenue to increase the connectivity between the individual empirically-based research theories.

In Luhmann's view, modern society evolves primarily according to the principal of functional differentiation. His theory offers an explanation for the emergence of autonomous communication within society. Such systems continue selfreproducing their unique communication formats as operationally closed to their respective environments, while observing problems pertinent to their particular functions to the society. Society is conceived as a particular social system, which contains all possible communications and nothing more; consequently, that is a world society with nation-states as its subunits (see Pfeffer and Stichweh, 2015). This offers a possibility for distancing analysis from methodological nationalism, which has often framed studies on higher education and innovation policy. Furthermore, societal functions of systems, or their codes of communication, do not conflate. Differentiated systems (e.g. science, education, economy and politics) do not communicate directly with each other, but they can communicate about observing each other.

All articles of this special issue refer to the need of sharpening theoretically meaningful distinctions that could enhance describing the nature of increasingly complex boundary controversies, that is, the hybridity in organising relations of universities in societal environments. Luhmann's conceptuality offers various tools for grasping 
the interdependency of societal systems as they become organised in the university and system of higher education. The concept of 'structural coupling', which replaces the input-output distinction of older system theory, appears to be particularly fertile for describing a system's selective openness to its self-constructed environment. The empirical analysis of such couplings might be one promising way of describing internal changes in the university in regard to its traditional ways of organising the interdependence between the function systems of education (teaching for the purpose of effectuating psychic systems of persons), science (controlling the uncertainty by means of defining researchable problems) and administration or research management which draws upon a system of politics (producing binding decisions). Thus, instead of conflating their codes, these functional systems can resonate with each other, meaning that a given system's societal environment (i.e. another system) irritates or stimulates its internal state thus sensitising it to changes pertinent to its own structural state (Luhmann, 1986, 40). The more extensive the system's internal structure, the more likely it is that it resonates with its environment. For example, the more there exists variety in the disciplinary structure of science, the more likely it is that science is stimulated by its environment, such as education, economy or politics. In Luhmann's perspective, these sorts of influences are conceptualised as structural couplings between autonomous social systems and their self-constructed environments. The analysis suggests one to observe how the social system of science transcodes external issues and influences into topics of its own, or, vice versa, how scientific results become translated into forms that are useful, say, in the economy by way of patenting and licensing.

It is precisely these sorts of relations and translations between science, economy and other social systems that are in focus in the articles included in this special issue. For instance, notions of forward and reverse tailoring by Möllers point to the processes where scientists voluntary orientate their research to meet external expectations set by the research funding agencies. Although the concepts of tailoring introduced by her are useful in understanding the processes that are taking place here, further theorisation with the help of ideas provided by Luhmann would provide additional benefits, simultaneously as the intellectual value provided by the original conceptualisation would not be diminished. In Luhmann's conceptuality, forward and backward tailoring could be regarded as a process reflexivity where special semantics are produced within the system of science so as to constructively sensitise the operations of science to external policy conditions mediated by governmental research funding. The question here is not about a sheer terminological shift from one analytic language, that of Möllers, to another, i.e. Luhmann. Rather, the advantage of trying to work towards a more abstract conceptuality is to open up an avenue for thinking and communicating across individual case studies and research theories they have developed. With the help of the conceptuality developed at the level of general sociological theory, such as that of Luhmann, intellectual integration of otherwise relatively heterogeneous field of research might be achieved.

Thus, the back and forth tailoring introduced by Möllers and considerations of boundary work described by Vuolanto could together be interpreted as specific reflection performances that produce relevant schemes for organisational (whether a research group or discipline in the university) decisions. In situations like these, the inside/outside distinction of science is maintained as the organisation aims to reduce the contingency in its environment, whether in gaining academic recognition for a new specialisation or adjusting research problems to meet the requirements of external funding. In such internal orientations, specific decision schemes are deployed, and these are conditioned by organisation-specific arrangements that have been previously decided upon more established structural couplings with the societal environment, say stable partner structures or other contractual forms. The latter, however, are not brought about arbitrarily but, instead, along the premises that different function systems develop to meet historically changing boundary conditions.

The notion of technoscience, as mentioned by Möllers, can very well be a semantic level indica- 
tion of a mutual learning process between the two societal forms of knowledge production, science and economics. Under such structural conditions, scientific knowledge production becomes more responsive to research, development and innovation-oriented (R\&D\&l) policy programmes. In addition to the possible internal correctives implied in the mutual long-term learning between the systems of science and economics, the policy programme formulation of R\&D\&l could be viewed as a kind of specific contingency formula developed within politics so as to modify the premises of internal steering within universities to better adapt the organisation to the external political and economic environments (see Kantasalmi, 2015).

Based on Proctor's (2008) views on ignorance, Fernández Pinto discusses the genre of studies with a constructivist view on ignorance, called agnotology, and then synthesises the main practices of constructing ignorance in research driven by the tobacco industry. She demonstrates the fertility of such taxonomy in understanding the strategies of ignorance production in current controversies over climate change, pharmaceuticals and financial crisis (see also Kleinman and Suryanarayanan, 2013). This is an important viewpoint as long as the R\&D\&l policy regime seeks to increase the variety of knowledge production, either via the detailed allocation of public research funds or by austerity measures reducing university science's relative portion in the R\&D\&l expenses. Both of these mechanisms offer space for recruiting university trained doctoral students and PhDs into development and innovation driven research programmes in private companies. Along such development the variety of doctoral training programmes increases within organisations of higher education (Kantasalmi, 2015; Kehm and Teichler, 2016) and, in consequence, the selective openness of science and tertiary schooling to their respective societal environment alters, e.g. in regard to researchers' labour markets. Such an increase in the organisational proximity between the university and industry points to the core of the global system of scientific communication, which is basically processing meaning as guided by concerns over true and untrue statements. Thus, the possible biasing effects produced, for instance, by the research funding sources are supposed to be neutralised in the course of global science communication, and by means of its institutionalised ways of organising the production of new knowledge.

The classified knowledge of industriallyoriented science with its noxious societal consequences has already awoken worrying dystopias (e.g. Krimsky, 2003). More recently, the urge for speedy dissemination of novel information via the technologically empowered mass media is effectively intervening the loci of different knowledge forms. Such situational complexity is underlined by all of the authors of this special issue, as well as much of the STS literature discussed in this introductory article. Drawing on Bourdieusian presumptions of the primacy of power, Münch (2015), for instance, views harmful effects in hybrids, like the ones discussed by Möllers, Vuolanto and Pinto. In reference to systems theoretical concept of structural coupling - also a hybrid for him - he envisions the economisation of science, based on political steering, to result in conflation of institutional logics of science and economy as a consequence of which science would lose its autonomy, and claims that systems theory has limits to enfold such hybrid forms in politically meaningful ways (for contrary claims, see e.g. Karafillidis, 2015). ${ }^{1}$ This should not be taken as an unavoidable outcome, however, as each of the functionally differentiated systems, such as science, can generate several programmes according to which it operates. Organisations, like universities, are carriers of such programmes and allow different forms of couplings to be made, say, between innovations expectations of the economy and university research and teaching programmes. Such situational complexity frames the daily interaction between individual minds, however, and it is currently further confused due to the deliberate production of ignorance, i.e. agnotology, which can be motivated not only by lucrative commercial aspirations, but even on the basis of our differing moral valuations (see Proctor, 2008: 9).

\section{Conclusion}

The articles published in this special issue all point to the relationships between science, university 
and society as well as the related transformations in the organisation of the university. The coevolution of education and science has brought about adaptations in the university ever since the socially more inclusive systems of higher education started to emerge in the $19^{\text {th }}$ century. The post-Second World War expansion of the system of higher education, both in terms of enrolments and in the number of organisations of tertiary schooling (Meyer et al., 2007), suggests asking whether the institutionalised coupling of education and science has loosened. In other words, universities, as part of a complex system of higher education, are starting to emphasise the social form of school, simultaneously as science is starting to emphasise its new social forms of collective, industrially oriented knowledge production. The consistency of the scientific labour force is still largely regulated by what Kant viewed as the core of the university, i.e. the factory-like (fabrikenmäs$s i g)^{2}$ production of doctors, but along with the expansion of doctorates, the inner logic of schooling has removed the significant level of scientific education from post-graduate schools into the post-doctoral training programmes, which may very well have their organisational loci outside of the university system. Thus, the legitimacy of the $R \& D \& I$ contingency formula offers a space for the emergence of entirely new organisational arrangements as for the continuation of publicly funded industrial doctorates (see Kantasalmi, 2015).

All of the authors in this volume capture the relevant trends with respect to the academy's current dynamics, and they do so both interestingly and with a high level of quality. Because of their focus on the empirical phenomena in specific contexts, there is, however, an opportunity for increasing theoretical connectivity between the studies at a more abstract level, an effort which would in our view also serve future empirical research on the current transformations. A discussion of the analyses provided by the authors at a more general theoretical level might thus allow for beneficial insights into the complex relationships that the university organisation has encountered in its current societal environment. The lead metaphors, such as Mode 2 knowledge production or the triple helix of university-industry-government relations, only point to the relevant and topical phenomena, simultaneously as the real challenge is how to adequately focus and conceptualise the descriptions so as to provide fruitful linkages between different interpretations. The papers published in this volume do a valuable job in continuing this line of thought. A characteristic of high-quality empirical research is in our view that it opens up more interpretative avenues than it closes. The three papers published here are of this sort and, therefore, they spurred our thinking towards an interpretative experiment, which could further advance our understanding of the phenomena taking place at the borders of science, university and society. This sort of theoretical work, which would make use of the general theoretical understanding of learning and knowing is, however, a collective mission designed for the interdisciplinary community of researchers. In achieving this goal, the recent developments in systems theory might provide a sufficiently general conceptual ground for enhancing connections between different research theories that regulate empirical studies. 


\section{References}

Albert M and McGuire W (2014) Understanding Change in Academic Knowledge Production in Neoliberal Era. In: Frickel S and Hess DJ (eds) Fields of Knowledge: Science, Politics and Publics in the Neoliberal Age (Political Power and Social Theory, Volume 27). Bingley: Emerald, pp. 33-57.

Arnoldi J (2007) Universities and the Public Recognition of Expertise. Minerva 45(1): 49-61.

Beddoes K (2013) Methodology Discourses as Boundary Work in the Construction of Engineering Education. Social Studies of Science 44(2): 293-312.

Boggio A, Ballabeni A and Hemenway D (2016) Basic Research and Knowledge Production Modes: A View from the Harvard Medical School. Science, Technology, \& Human Values 41(2): 163-193.

Brown MB (2010) Coercion, Corruption, and Politics in the Commodification of Academic Science. In Radder $\mathrm{H}$ (ed) The Commodification of Academic Research. Science and the Modern University. Pittsburgh, PA: University of Pittsburgh Press, pp. 259-276.

Bychkova O (2016) Innovation by Coercion: Emerging Institutionalization of University-Industry Collaborations in Russia. Social Studies of Science 46(4): 511-535.

Clarke A and Star SL (2008) The Social Worlds Framework: A Theory/Methods Package. In: Hackett EJ, Amsterdamska O, Lynch M and Wajcman J (eds) The Handbook of Science and Technology Studies. Cambridge, MA: The MIT Press, pp. 113-137.

Etzkowitz H (1998) The Norms of Entrepreneurial Science: Cognitive Effects of the New University-Industry Linkages. Research Policy 27(8): 823-33.

Etzkowitz H (2008) The Triple Helix: University-Industry-Government Innovation in Action. New York, NY: Routledge.

Etzkowitz H (2011) Normative Change in Science and the Birth of the Triple Helix. Social Science Information 50(3-4):549-568.

Fochler M (2016) Beyond and Between Academia and Business: How Austrian Biotechnology Researchers Describe High-Tech Startup Companies as Spaces of Knowledge Production. Social Studies of Science 46(2): 259-281.

Gibbons M (2000) Mode 2 Society and the Emergence of Context-Sensitive Science. Science and Public Policy 27(3): 159-63.

Gibbons M, Limoges C, Nowotny H, Schwartzman S, Scott P, and Trow M (1994) The New Production of Knowledge: The Dynamics of Science and Research in Contemporary Societies. London: Sage.

Gieryn T (1999) Cultural Boundaries of Science: Credibility on the Line. Chicago, IL: Chicago University Press.

Godin B (1998) Writing Performative History: The New New Atlantis? Social Studies of Science 28(3):465-483.

Hammershøj LG (2015) Diagnosis of the Times vs Description of Society. Current Sociology Monograph 63(2): 140-154.

Hessels LK (2010) Science and the Struggle for Relevance. PhD Thesis, Utrecht University, The Netherlands.

Hicks D and Wang J (2013) The New York Times as a Resource for Mode 2. Science, Technology, \& Human Values 38(6): 851-877.

Hoffman SG (2015) Thinking Science with Thinking Machines: The Multiple Realities of Basic and Applied Knowledge in a Research Border Zone. Social Studies of Science 45(2): 242-269.

Irwin A (2015) Science, Public Engagement with. In: Wright, JD (ed.) International Encyclopedia of the Social \& Behavioral Sciences 2 edn, vol 11. Amsterdam: Elsevier Science, pp. 255-260.

Joas H and Knöbl W (2009) Social Theory: Twenty Introductory Lectures. Cambridge: Cambridge University Press. 
Kantasalmi K (2015) Universities and the Contingencies in Politics of Research, Development and Innovations: Finnish Reform of Doctoral Programs. In: Langemeyer I, Fischer M and Pfadenhauer M (eds) Epistemic and Learning Cultures: Wohin sich Universitäten entwickeln. Weinheim und München: Beltz Juventa, pp. 115-137.

Karafillidis A (2015) Formale Bedingungen von Hybridität und nicht-moderne Beobachter. In: Kron T (ed) Hybride Sozialität - Soziale Hybridität. Weilerswist: Velbrück Wissenschaft, pp. 223-246.

Kehm BM and Teichler U (2016) Doctoral Education and Labor Market: Policy Questions and Data Needs. In: Gokhberg L, Shmatko N and Auriol L (eds) The Science and Technology Labor Force: The Value of Doctorate Holders and Development of Professional Careers. Switzerland: Springer, pp. 11-29.

Kleinman DL and Suryanarayanan S (2012) Dying Bees and the Social Production of Ignorance. Science, Technology, \& Human Values 38(4): 492-517.

Knudsen M (2007) Structural Couplings between Organizations and Function Systems. Looking at Standards in Health Care. Cybernetics and Human Knowing 14(2-3): 111-131.

Krimsky S (2003) Science in the Private Interest: Has the Lure of Profits Corrupted Biomedical Research? Lanham, MD: Rowman \& Littlefield.

Kurath M (2015) Architecture as a Science: Boundary Work and the Demarcation of Design Knowledge from Research. Science \& Technology Studies 28(3): 81-100.

Lam A (2010) From 'Ivory Tower Traditionalists' to 'Entrepreneurial Scientists'? Academic Scientists in Fuzzy University-Industry Boundaries. Social Studies of Science 40(2): 307-40.

Lave R, Mirowski P and Randalls S (2010) Introduction: STS and Neoliberal Science. Social Studies of Science 40(5): 659-675.

Leith P, Haward M, Rees C and Ogier E (2016) Success and Evolution of a Boundary Organization. Science, Technology, \& Human Values 41(3): 375-401.

Luhmann N (1986) Ökologische Kommunikation. Opladen: Wesdeutscher Verlag.

Luhmann N (1990) Die Wissenschaft der Gesellschaft. Frankfurt am Main: Suhrkamp.

Luhmann N (1995) Social Systems. Stanford, CA: Stanford University Press.

Luhmann N (2012) Theory of Society. Vol I. Stanford, CA: Stanford University Press.

Luhmann N (2013) Theory of Society. Vol. II. Stanford, CA: Stanford University Press.

McLevey J (2015) Understanding Policy Research in Liminal Spaces: Think Tank Responses to Diverging Principles of Legitimacy. Social Studies of Science 45(2): 270-293.

Marginson S and Considine M (2000) The Enterprise University: Power, Governance and Reinvention in Australia. Cambridge: Cambridge University Press.

Merton RK (1938) Science, Technology and Society in Seventeenth-Century England. Osiris 4(2): 360-632.

Meyer JW, Ramirez FO, Frank DO and Schoffer E (2007) Higher Education as an Institution. In Gumport PJ (ed) Sociology of Higher Education. Baltimore, MD: The Johns Hopkins University Press, pp. 187-221.

Miettinen R, Tuunainen J and Esko T (2015) Epistemological, Artefactual and Interactional-Institutional Foundations of Social Impact of Academic Research. Minerva 53(3), 257-277.

Mirowski P (2011) Science-Mart: Privatizing American Science. Cambridge, MA: Harvard University Press.

Münch R (2015) Akademischer Kapitalismus: harmloser oder gefährlicher Hybrid? In: Kron T (ed) Hybride Sozialität - Soziale Hybridität. Weilerswist, Velbrück Wissenschaft, pp. 223-246.

Neave G (1979) Academic Drift: Some Views from Europe. Studies in Higher Education 4(2): 143-159. 
Nowotny H, Scott P and Gibbons M (2001) Re-Thinking Science: Knowledge and the Public in an Age of Uncertainty. Cambridge: Polity Press.

Owen-Smith J (2003) From Separate Systems to a Hybrid Order: Accumulative Advantage Across Public and Private Science at Research One Universities. Research Policy 32(6): 1081-1104.

Owen-Smith J (2006) Commercial Imbroglios: Proprietary Science and the Contemporary University. In: Frickel S and Moore K (eds) The New Political Sociology of Science: Institutions, Networks, and Power. Madison, WI:The University of Wisconsin Press, pp. 63-90.

Parker JN and Crona B (2012) On Being All Things to All People: Boundary Organizations and the Contemporary Research University. Social Studies of Science 42(2): 262-289.

Parthasarathy S (2012) Building Genetic Machine: Breast Cancer, Technology, and the Comparative Politics of Health Care. Cambridge, MA: MIT Press.

Pfeffer T and Stichweh R (2015) Systems Theoretical Perspectives on Higher Education Policy and Governance. In: Huisman J, de Boer H, Dill DD and Souyto-Otero M (eds) The Palgrave International Handbook of Higher Education Policy and Governance. Houndmills: PalgraveMacmillan, pp. 152-175.

Powell WW, White DR, Koput KW and Owen-Smith J (2005) Network Dynamics and Field Evolution: The Growth of Interorganizational Collaboration in the Life Sciences. The American Journal of Sociology 110(4): 1132-1205.

Proctor NR (2008) Agnotology: A Missing Term to Describe the Cultural Production of Ignorance (and Its Study). In: Proctor RN and Schiebinger L (eds) Agnotology: The Making and Unmaking of Ignorance. Stanford, CA: Stanford University Press, 1-33.

Radder H (2010) The Commodification of Academic Research. Science and the Modern University. Pittsburgh, PA: University of Pittsburgh Press.

Randalls, S (2010) Weather Profits: Weather Derivatives and the Commercialization of Meteorology. Social Studies of Science 40(5): 705-730.

Rhoades G and Slaughter S (2004) Academic Capitalism in the New Economy. Baltimore, MD: The Johns Hopkins University Press.

Shapin S (1988) Understanding the Merton Thesis. Isis 79(4): 594-605.

Slaughter S and Leslie LL (1997) Academic Capitalism: Politics, Policies, and the Entrepreneurial University. Baltimore, MD: The Johns Hopkins University Press.

Thackray A (ed) (1998) Private Science: Biotechnology and the Rise of the Molecular Sciences. Philadelphia: University of Pennsylvania Press.

Tuunainen J (2001) Constructing Objects and Transforming Experimental Systems. Perspectives on Science 9(1): 78-105.

Tuunainen J (2005) Contesting a Hybrid Firm at a Traditional University. Social Studies of Science 35(2):173210.

Tuunainen J and Knuuttila T (2009) Intermingling Academic and Business Activities: A New Direction for Science and Universities? Science, Technology, \& Human Values 34(6):684-704.

Wadmann S (2014) Physician-Industry Collaboration: Conflicts of Interest and the Imputation of Motive. Social Studies of Science 44(4): 531-554.

Ylijoki O-H, Lyytinen A and Marttila L (2011) Different Research Markets: A Disciplinary Perspective. Higher Education 62(6): 721-740.

Ziman J (2000) Real Science: What It Is, and What It Means. Cambridge: Cambridge University Press. 


\section{NOTES}

1 For the preference of the Luhmannian notion of 'structural coupling' even in the Bourdieusian frame, see Arnoldi (2007: fn. 51). For an empirically productive reading of the 'structural couplings' in Luhmann's theory, see Knudsen (2007).

2 By this, Kant in "Der Streit der Fakultäten" refers to an organisation principle resembling the division of labor where universities create doctors for the learnedness and scholarship in society. Today, we would first think the massive scale in tertiary schooling of doctors, and surprising variations in contents of doctoral programmes, such as the "industrial doctorates" in the European Higher Education Area. 